\title{
Tingkat Kepatuhan Penggunaan Alat Pelindung Diri (APD) Tenaga Kesehatan di Rumah Sakit Pada Masa Pandemi COVID-19 : Literature Review
}

\author{
Yogie Prasethya Al Hakim ${ }^{1 *}$, Mokhamad Arifin ${ }^{2}$ \\ 1,2 Sarjana Keperawatan, Universitas Muhammadiyah Pekajangan Pekalongan, Indonesia \\ *email: yogieprasethyaalhakim.9a.19@gmail.com ${ }^{1}$
}

\begin{abstract}
The COVID-19 virus is very easy to spread, especially through droplets from infected people to others. This makes health workers vulnerable to infection. To overcome this problem. it is necessary to use personal protective equipment (PPE) which aims to protect health workers from the COVID-19 virus. To describe the compliance level of health workers with the personal protective equipment (PPE) in hospitals during the COVID-19 pandemic. A research literature review of 5 articles accessed from online databases such as Google Scholar and PubMed published from 2020-2021. The research used the Systematic Reviews and MetaAnalysis (PRISMA) checklist. The results of this literature review showed that, from a total of 1496 respondents, 1158 respondents (77.4\%) had a good level of compliance with personal protective equipment (PPE) usage. Based on the results, it can be concluded that the health workers have a good level of compliance with the PPE usage during the COVID-19 pandemic. This literature review research is expected to be new knowledge, insight, and reference for health workers regarding the compliance with the use of personal protective equipment (PPE), especially during the COVID-19 pandemic.
\end{abstract}

Keywords: Personal Protective Equipment (PPE), COVIID-19, Adherence, Health Workers'.

\begin{abstract}
Abstrak
Virus COVID-19 sangat mudah menyebar terutama melalui droplet dari orang yang terinfeksi kepada orang lain. Hal ini mengakibatkan petugas kesehatan rawan untuk terinfeksi. Untuk mengatasi masalah tersebut maka diperlukan penggunaaan alat pelindung diri (APD) yang bertujuan untuk melindungi petugas kesehatan dari virus COVID-19. Untuk mengetahui bagaimana tingkat kepatuhan penggunaan alat pelindung diri (APD) tenaga kesehatan di rumah sakit pada masa pandemi COVID-19. Penelitian literature review dari 5 artikel mengakses database online seperti Google Scholar dan PubMed yang di publikasi dari tahun 2020-2021. Instrumen telaah kritis yang digunakan yaitu instrument PRISMA checklist. Hasil penelitian literature review ini menunjukan diketahui dari total responden sebanyak 1496 orang, sebanyak 1158 responden dengan presentase $(77,4 \%)$ memiliki kepatuhan yang baik dalam penggunaan alat pelindung diri (APD). Pada penelitian literature review kali ini didapatkan hasil berupa tingkat kepatuhan penggunaan APD yang baik oleh petugas kesehatan di masa pandemi COVID-19. Penelitian literature review ini diharapkan dapat menjadi pengetahuan, wawasan dan referensi baru untuk tenaga kesehatan terkait kepatuhan penggunaan alat pelindung diri (APD) terutama pada masa pandemi COVID-19.
\end{abstract}

Kata kunci: Alat Pelindung Diri (APD), COVID-19, Kepatuhan, Tenaga Kesehatan.

\section{Pendahuluan}

Coronavirus Disease 2019 (COVID-19) merupakan penyakit dalam ketegori baru yang belum sempat diidentifikasi sebelumnya pada manusia. Virus pemicu COVID-19 ini dinamakan Sars-CoV-2. Virus corona dapat ditularkan antar individu ke individu lain melalui droplet ataupun percikan batuk (bersin). Tanda dan gejala umum infeksi covid19 termasuk gejala gangguan respirasi akut seperti demam, batuk, dan sesak napas. Masa inkubasi rata-rata adalah 5 - 6 hari dengan masa inkubasi demam, batuk, dan 


\section{Prosiding Seminar Kesehatan Nasional 2021 Lembaga Penelitian dan Pengabdian Masyarakat Universitas Muhammadiyah Pekajangan Pekalongan}

sesak napas. Pada kasus yang parah, covid-19 dapat menimbulkan pneumonia, sindrom pernapasan akut, gagal ginjal, dan bahkan kematian [1].

Berdasarkan dari proses penularan virus tersebut, dari sudut pandang tenaga kesehatan wajib menggunakan Alat Pelindung Diri (APD). Hal ini berkaitan dengan Undang-Undang Nomor 36 Tahun 2009 tentang kesehatan pasal 165 yang berbunyi pengelola tempat kerja wajib melakukan segala bentuk upaya kesehatan melalui upaya pencegahan, peningkatan, pengobatan dan pemulihan bagi tenaga kerja. Maka dari itu setiap rumah sakit wajib menjamin kesehatan serta keselamatan baik terhadap pasien, penyedia layanan atau pekerja maupun masyarakat sekitar dari berbagai potensi bahaya yang ada di rumah sakit [2].

Pada masa pandemi seperti saat ini dapat menggunakan APD yang dianjurkan atau disarankan untuk mencegah penularan virus COVID 19 seperti pelindung wajah (face shield), masker (mask) dan sarung tangan (gloves). Tujuan memakai alat pelindung diri tersebut untuk menghindari paparan virus ke dalam tubuh ataupun menularkan virus ke orang lain [3].

Penggunaan APD dapat dinilai sejauh mana tiap individu patuh dalam menggunakannya. Kepatuhan yang dimaksud pada bagian ini lebih dikhususkan dalam hal penggunaan APD. kepatuhan mempunyai persepsi dan pengaruh yang berbedabeda akibat dari usia, keadaan fisik, keturunan, tingkat pendidikan dan masih banyak lagi variable-variabel yang lainnya. Hal ini berdampak pada persepsi dari informasi yang datang, diterima dan dipelajari darisetiap individu [4].

Pada penelitian Zhao [5] tentang "Personal protective equipment protecting healthcare workers in the Chinese epicentre of COVID-19. "Di China pada tahun 2020 dengan membagi jenis petugas kesehatan (dokter, perawat dan lain-lain), wilayah kerja dan menilai frekuensi penggunaan setiap jenis APD (sarung tangan, gaun isolasi, masker medis, seragam pelindung medis, respirator N95 atau FFP2, tutup kepala dan pelindung wajah atau kacamata) menjadi 3 kelompok. Kemudian didapatkan hasil bahwa kelompok 3 lebih banyak menggunakan respirator N95 atau FFP2, pelindung wajah atau kacamata dan seragam pelindung medis daripada kelompok lain.

Penelitian Ismawati [6] di RSUD Dr. Soetomo tahun 2020 tenaga kesehatannya seperti perawat, doketer, transporter dan petugas administrasi yang berada di Gedung Bedah Pusat Terpadu (GBPT) mempunyai tingkat kepatuhan yang perlu ditingkatkan dalam penggunaan masker, penerapan cuci tangan, maupun penerapan social distancing pada petugas kesehatan. Terutama pada tenaga administrasi di rumah sakit tersebut yang tidak patuh dalam menggunakan masker. Sedangkan dalam penelitian Widjasena [7] tahun 2020 tentang "Studi Literatur Terkait Analisis Perilaku Kepatuhan Penggunaan Alat Pelindung Diri (APD) Pada Tenaga Kesehatan Saat Wabah Pandemi Corona Virus (Covid-19)" mengutarakan, di masa pandemi COVID-19 masih terdapat perilaku kepatuhan yang cukup rendah dalam menggunakan APD. Hal itu juga berkaitan dengan masa kerja, jenis profesi, pengetahuan, sikap, persepsi tenaga kerja serta ketidak nyamanan menggunakan APD, nilai, peraturan yang belum jelas dan ketersediaan APD. 


\section{Prosiding Seminar Kesehatan Nasional 2021 Lembaga Penelitian dan Pengabdian Masyarakat Universitas Muhammadiyah Pekajangan Pekalongan}

Berdasarkan penelitian diatas, maka peneliti tertarik untuk melakukan penelitian tentang "Tingkat Kepatuhan Penggunaan APD (Alat Pelindung Diri) Para Tenaga Kesehatan di Rumah Sakit Pada Masa Pandemi.

\section{Metode}

Proses seleksi artikel menggunakan database online seperti Google Scholar dan PubMed dengan kriteria inklusi seperti tahun artikel dalam rentan waktu 2020-2021, artikel dapat diunduh secara full text, responden merupakan tenaga kesehatan dan area penelitian yang berada di rumah sakit. Sedangkan untuk kriteria eksklusi seperti hasil artikel tidak lengkap, tidak terdapat abstrak dan hasil penelitian tidak sesuai dengan tujuan penelitian ini. Dari hal tersebut kemudian didapatkan 5 artikel yang dapat dilakukan literature review.

\section{Hasil dan Pembahasan Hasil}

Penelitian literature review kali ini menggunakan 5 artikel baik nasional maupun internasional. Berdasarkan data artikel tersebut kemudian diolah dengan tujuan untuk mencari data terkait dengan tingkat kepatuhan penggunaan APD tenaga kesehatan terutama pada masa pandemi COVID-19. Hasil Analisa data dari 5 artikel terdapat data responden berdasarkan tingkat kepatuhan dalam penggunaan alat pelindung diri (APD) yang patuh dan tidak patuh dalam penelitian [6], [8], [9], [10] dan [11] antara lain sebagai berikut:

Tabel 1. Kepatuhan penggunaan alat pelindung diri (APD)

\begin{tabular}{lcc}
\hline Kepatuhan & $\mathrm{N}$ & $\%$ \\
\hline Patuh & 1158 & 77,4 \\
\hline Tidak Patuh & 338 & 22,6 \\
\hline Total & 1496 & 100 \\
\hline
\end{tabular}

Berdasarkan table 4.1 dapat diketahui dari total responden sebanyak 1496 orang, sebanyak 1158 responden dengan presentase $(77,4 \%)$ memiliki kepatuhan yang baik dalam penggunaan alat pelindung diri (APD).

\section{Pembahasan}

Hasil literature review ke- 5 artikel tersebut didapatkan data mengenai kepatuhan penggunaan APD petugas kesehatan pada masa pandemi COVID-19 memperoleh hasil kepatuhan yang baik, dengan total responden sebanyak 1496 orang terdapat 1158 dengan presentase $77,4 \%$ responden patuh dalam menggunakan alat pelindung diri. Hal ini juga sejalan dengan penelitian yang dilakukan oleh Kanu [8] tahun 2021 dimana mendapatkan hasil yang baik dalam kepatuhan penggunaan alat pelindung diri. Hal ini dikarenakan kepatuhan memiliki faktor pendukung, seperti sikap yang didasari akan himbauan yang mendasari seseorang terdorong dalam melakukan suatu tindakan terlebih lagi tenaga kesehatan berhubungan langsung dalam melakukan 


\section{Prosiding Seminar Kesehatan Nasional Lembaga Penelitian dan Pengabdian Masyarakat Universitas Muhammadiyah Pekajangan Pekalongan}

perawatan kesehatan [6]. Selain itu sikap merupakan sebuah kisiapan ataupun reaksi terhadap stimulus dengan cara tertentu, apabila seseorang dihadapkan dengan sebuah stimulus yang menghendaki adanya respon sebuah pola perilaku ataupun kesiapan dalam antisipatif untuk menyesuaikan diri dengan situasi sosial yang telah dikondisikan. Faktor lainnya yang dapat mempengaruhi kepatuhan merupakan pendidikan, namun peningkatan pengetahuan tidak selalu menyebabkan perubahan perilaku dalam diri seseorang kecuali orang tersebut mendapatkan motivasi yang cukup kuat untuk bertindak atas dasar pengetahuan yang dimilikinya [2].

Penelitian literature review yang berada di Indonesia mengenai kepatuhan dalam penggunaan alat pelindung diri mendapatkan hasil kepatuhan yang rendah. Dimana dalam penelitian yang dilakukan oleh Ismawati [6] yang mendapatkan hasil 34 responden dari total 50 orang responden mempunyai kepatuhan yang rendah. Rendahnya kepatuhan dalam beberapa hal dapat dikarenakan kebijakan maupun ketersediaan alat pelindung diri yang masih minim. Kebijakan menjadikan faktor yang berpengaruh terhadap seseorang dikarenakan himbauan yang dapat menjadikan seseorang dapat mematuhi aturan yang berlaku, terlebih lagi kalangan pekerja yang menghadapi pasien maupun keluarga pasien secara langsung [6]. Ketersediaan alat pelindung diri yang minim merupakan faktor yang berpengaruh dalam kepatuhan, alat pelindung diri merupakan sebuah tantangan global dalam menghadapi COVID-19 [8]. Sarana APD yang lengkap mampu mendukung perilaku yang baik dalam melakukan prosedur kewaspadaan secara universal [2].

Dampak dari ketidak patuhan dalam menggunakan alat pelindung diri seperti terinfeksi oleh virus COVID-19 ketika sedang bekerja. Hal ini juga dapat berhubungan dengan tingkat kematian tenaga kesehatan di Indonesia yang melonjak. Dalam laporan mengenai COVID-19 terdapat 978 tenaga kesehatan yang meninggal dunia akibat terinfeksi virus COVID-19 yang terhitung hingga tanggal 24 Juni 2021. Sedangkan pada 6 Juli 2021 terdapat lonjakan yang sangat derastis mengenai kasus meninggalnya tenaga kesehatan akibat terinfeksi virus COVID-19 yaitu sebanyak 1066 jiwa.

Penelitian literature review yang berasal dari luar negeri seperti di Bangladesh, Sierra Leone, Nigeria dan Kermanshah menunjukan perilaku kepatuhan yang baik dalam penggunaan alat pelindung diri. Pada penelitian Kanu [8] di Sierra Leone tenaga kesehatan sendiri mempunyai pengetahuan mengenai pencegahan, penularan, penyebab dan pengobatan terkait COVID-19 yang baik yang menyebapkan tenaga kesehatan di Sierra Leone mempunyai sikap yang positif terhadap COVID-19. Namun terdapat kendala yang berpengaruh dalam menyikapi COVID-19 seperti kurang ketersediaan fasilitas kesehatan seperti masker N95 atau masker bedah, sarung tangan, pelindung wajah dan baju pelindung.

Penelitian yang dilakukan oleh Ejeh [9] di Nigeria mempunyai faktor yang berpengaruh dalam kepatuhan penggunaan alat pelindung diri seperti pengetahuan yang baik mengenai virus COVID-19, namun dalam penelitian ini responden perempuan lebih dirugikan dibandingkan responden laki-laki dalam ketersediaan dan aksesibilitas APD. Hal ini dikarenakan laki-laki di Nigeria dianggap memiliki kendali atas sumber daya dibandingkan perempuan. Sedangkan penelitian Maleki [10] di 


\section{Prosiding Seminar Kesehatan Nasional Lembaga Penelitian dan Pengabdian Masyarakat Universitas Muhammadiyah Pekajangan Pekalongan}

Kermanshah didapatkan hasil yang positif dalam pengetahuan, sikap maupun perilaku yang sangat baik dalam menyikapi COVID-19. Namun kendala dalam penelitian ini merupakan ketersediaan APD yang masih kurang seperti masker N95, pakaian sekali pakai, sarung tangan, kacamata dan yang lainnya. Perlindungan diri yang kurang memadai ketika menangani pasien pada awal epidemi sehingga hal ini menjadikan alasan para petugas terkena virus Corona.

Di Bangladesh yang dilakukan oleh Hossain [11] terdapat kepatuhan penggunaan alat pelindung diri yang baik dari 203 respondendengan total responden penelitian sebanyak 393 orang. Hal ini dikarenakan motivasi dan pengetahuan mengenai perlindungan, penularan dan pencegahan mengenai COVID-19 yang baik terhadap petugas kesehatan disana yang mengakibatkan kepatuhan yang baik dalam hal penggunaan alat pelindung diri. Namun rumah sakit swasta di Bangladesh mempunyai kualitas APD yang lebih baik dengan kualitas tinggi dibandingkan rumah sakit yang dibiayai oleh negara, hal ini dikarenakan sumber keuangan rumah sakit swasta berasal dari klien mereka.

Dari penelitian yang dilakukan di 4 negara lain yang berbeda dapat diketahu bahwa faktor utama dalam kepatuhan petugas menggunakan alat pelindung diri dapat berkaitan dengan jumlah ketersediaan alat pelindung diri yang ada. Ketersediaan alat pelindung diri yang minim merupakan faktor yang berpengaruh dalam kepatuhan, alat pelindung diri merupakan sebuah tantangan global dalam menghadapi COVID-19 [8]. Pengaruh lain dari kepatuhan dapat berupa motivasi mengenai persepsi bahaya dan resiko selain itu motivasi yang kuat oleh tanggung jawab perlindungan kepada anggota keluarga [11]. Selain itu pengetahuan yang tinggi mengenai praktik dalam pencegahan penyakit menular dapat berperan dalam proses kepatuhan untuk menggunakan alat pelindung diri [9].

Pada jenis-jenis alat pelindung diri yang digunakan oleh petugas kesehatan yang terdapat pada ke- 5 artikel masker serta pakaian pelindung lebih sering digunakan oleh petugas kesehatan. Seperti yang terdapat dalam penelitian dari Ismawati [6], Kanu [8] dan Maleki [10] dimana petugas kesehatan lebih banyak menggunakan masker. Sedangkan dalam penelitian Ejeh [9] petugas kesehatan lebih sering menggunakan alat pelindung diri berjenis pakaian pelindung/gown. Kemudian dalam penelitian Hossain [11] hanya menyebutkan penggunaan alat pelindung diri meliputi masker, sarung tangan dan kacamata atau pelindung wajah.

\section{Kesimpulan}

Pada penelitian literature review kali ini dengan menggunakan 5 artikel yang berbeda didapatkan hasil dari total responden sebanyak 1496 orang, tingkat kepatuhan penggunaan APD yang baik oleh petugas kesehatan sebanyak 1158 $(77,4 \%)$ responden di masa pandemi COVID-19.

\section{Referensi}

[1] R. N. Putri, "Indonesia Dalam Menghadapi Pandemi Covid-19," Jurnal IImiah Universitas Batanghari Jambi, 20(2), pp. 705-709, 2020. 


\section{Prosiding Seminar Kesehatan Nasional 2021 Lembaga Penelitian dan Pengabdian Masyarakat Universitas Muhammadiyah Pekajangan Pekalongan}

[2] G. K. L. \&. S. R. Apriluana, " Hubungan antara usia, jenis kelamin, lama kerja, pengetahuan, sikap dan ketersediaan alat pelindung diri (APD) dengan perilaku penggunaan APD pada tenaga kesehatan. Jurnal Publikasi Kesehatan Masya," Jurnal Publikasi Kesehatan Masyarakat Indonesia (JPKMI), pp. 82-87, 2016.

[3] Y. Y. T. T. C. \&. O. J. R. Theopilus, "Analisis Risiko Produk Alat Pelindung Diri (APD) Pencegah Penularan COVID-19 untuk Pekerja Informal di Indonesia," Jurnal Rekayasa Sistem Industri, 9(2), pp. 115-134, 2020.

[4] S. Sutanta, "Hubungan Tingkat Pengetahuan Dengan Kepatuhan Cusi Tangan Perawat dan Bidan di Rumah Sakit Empat Lima," Jurnal Keperawatan GSH, 10(1), pp. 33-38, 2021.

[5] Y. L. W. L. Y. C. Y. L. P. Z. R. .. \&. H. J. Zhao, "Personal protective equipment protecting healthcare workers in the Chinese epicentre of COVID-19," Clinical Microbiology and Infection, 26(12), pp. 1716-1718., 2020.

[6] N. D. S. S. S. \&. H. S. Ismawati, "Hubungan Persepsi Petugas Kesehatan dengan Kepatuhan Terhadap Upaya Pencegahan Penyebaran Wabah Covid-19 di Area GBPT RSUD Dr. Soetomo.," CoMPHI Journal: Community Medicine and Public Health of Indonesia Journal, 5(1), pp. 101-108, 2020.

[7] B. \&. W. I. Widjasena, " Studi Literatur Terkait Analisis Perilaku Kepatuhan Penggunaan Alat Pelindung Diri (APD) Pada Tenaga Kesehatan Saat Wabah Pandemi Corona Virus (Covid-19).," Jurnal IImiah Mahasiswa, 10(4), , pp. 105110., 2020.

[8] S. J. P. B. B. A. J. K. J. A. K. M. S. W. C. \&. K. J. S. Kanu, "Healthcare Workers' Knowledge, Attitude, Practice and Perceived Health Facility Preparedness Regarding COVID-19 in Sierra Leone.," Journal of multidisciplinary healthcare, 14, pp. 67-80, 2021.

[9] F. E. S. A. S. O. S. M. N. A. J. S. M. L. \&. O. K. O. Ejeh, "Knowledge, attitude, and practice among healthcare workers towards COVID-19 outbreak in Nigeria.," Heliyon, p. 6(11), 2020.

[10] S. N. F. F. K. F. M. H. F. \&. N. M. Maleki, "Knowledge, attitude and behavior of health care workers in the prevention of COVID-19.," Research Square, pp. 1-17, 2020.

[11] M. A. R. M. U. B. K. M. A. S. S. S. K. M. A. \&. H. M. D. H. Hossain, "Healthcare Workers' knowledge, attitude, and practice regarding personal protective equipment for the prevention of COVID-19.," Journal of Multidisciplinary Healthcare, pp. 14, 229-238, 2021. 